\title{
Development of scale to measure the perception of multistakeholders towards potential of dairy and goat production system for augmenting farmers' income
}

\author{
Santosh S Pathade ${ }^{1}$, BP Singh ${ }^{1}$ MR Verma ${ }^{2}$ and KI Pordhiya ${ }^{1}$
}

Received: 20 June 2019 / Accepted: 21 September 2019 / Published online: 31 December 2019

(c) Indian Dairy Association (India) 2019

\begin{abstract}
The present study was undertaken for development of equal appearing interval scale to measure perception of multistakeholders to assess the potential in dairy and goat production system to augment farmers' income. A list of 49 statements indicating positive as well as negative perception was considered for dairy and goat production system respectively. The judges' response was recorded on seven point continuum. The score was summed up to calculate scale and Q value for each statement. Final statements were selected on the basis of scale value $(>1.60)$ and $\mathrm{Q}$ value $(<1.60)$. The response of Stakeholders (LDOs, ACAH from Dept of Animal Husbandry and SMS of KVKs was recorded on three point continuum. The total individual respondent score was calculated by summing up the score of each statement given by individual. The scale so developed finally consist of 20 statements (11 positive and 9 negative) for dairy and 14 ( 8 positive and 6 negative) for goat production system. The reliability for whole scale was calculated using Spearman brown formula. It was found to be 0.90 and 0.86 for dairy and goat production system respectively, which is significant at 1 per cent level of significance.
\end{abstract}

Keywords: Dairy, Equal appearing interval, Perception, Q value, Reliability and validity, Scale value,

\footnotetext{
${ }^{1}$ Division of Extension Education, ICAR- ICAR-Indian Veterinary Research Institute, Izatnagar, Bareilly-243122, India

${ }^{2}$ Division of Livestock Economics, Statistics \& Information Technology ICAR- ICAR-Indian Veterinary Research Institute, Izatnagar, Bareilly243122, India

BP Singh $(\triangle)$

Division of Extension Education, ICAR- ICAR-Indian Veterinary Research Institute, Izatnagar, Bareilly-243122, India

Email: bpsingh_ext@rediffmail.com
}

\section{Introduction}

India has vast resource of livestock consisting of 300 million bovines and 135.2 million goats ( $19^{\text {th }}$ livestock census) which plays a vital role for improving socio-economic condition of rural mass. India is largest producer of milk (176.3MT) among the milk producing nations (NDDB, 2017). The species wise contribution in milk by indigenous buffaloes, crossbred cattle, non-descript buffaloes and goat is $35.4 \%, 25.4 \%, 13.8 \%$ and $3.5 \%$ respectively (Anonymous 2017-18). Total Milk production in Maharashtra state is $10402.150(000$ ”MT) of which 220.267 (000"MT) contributed by goat only (Anonymous, 2017-18). The percentage share of animals in milk is 27,22 and 18 percent for buffalo, indigenous cattle and goat respectively in Maharashtra state (19 ${ }^{\text {th }}$ livestock census). The highest growth of income is registered in livestock farming and it has increased its share in total income of a farm household from 4 per cent to 13 per cent during 20032013 (Report of committee on DFI, 2017). Similarly, goat provides assured source of income and act as a cushion against vulnerability of crop production system (Singh et al. 2013). Considering the potential in dairy and goat production system, there is a need to tap this potential in livestock production systems. Analyzing the perception of multistakeholders involved in dairy and goat production system is need of hour so as to develop the policy for doubling the farmers' income.

\section{Materials and Method}

Perception is the process of receiving information or stimuli from our environment and transforms it into psychological awareness (Van Den Ban and Hawkins, 1996). Perception is operationalized as the degree to which information or idea perceived by the multistakeholders (Animal Husbandry Department officers' viz. LDO, ACAH and DAHO and Subject matter specialist of KVKs) about potential in dairy and goat production system for augmenting farmers' income. The method of equal-appearing interval scale suggested by Turnstone's was applied for development of perception scale. The following steps were considered to measure the perception. 


\section{Collection of statements}

The statements of perception were collected from relevant professionals (extension specialist, agriculture scientist and personnel connected with animal husbandry) and available literature etc. The statements were then scrutinised and edited by applying criteria and guidelines suggested by Thurstone and Chave (1929), Edwards (1969). Out of large number of statements collected, 98 generalised perception statements, relevant and unique, comprised of 49 related to dairy and 49 to goat production system were initially selected.

\section{Judge's ratings of perception statements}

All the 98 statements were mailed to 100 judges, who were extension specialist, sociologist, scientist and professors from State Veterinary University and Research institutes viz. ICAR and MANAGE also persons with considerable practical experiences in dealing with dairy and goat production system. The judges were requested to sort out the 98 statements on 7point continuum i.e. strongly favourable, favourable, most favourable, neutral, most unfavourable, unfavourable and strongly unfavourable based on its degree of favourablenessunfavourableness for each statement. Out of 100 judges only 50 judges recorded their response and returned within span of 3 months. Out of 50 judges, 40 judges response finally retained and the response of 10 judges were eliminated.

\section{Calculation of scale and $Q$ values}

\section{Scale value}

Data of each statement were obtained from judges arranged in the form of three rows indicating frequency, frequency as proportions and cumulative proportions. Scale value was obtained by means of following formula.

$\mathrm{S}=l+(0.50-\Sigma P b) i \div P w$

Where $\mathrm{S}=$ the median or scale value of the statement

$\mathrm{l}=$ the lower limit of interval in which the median falls

$\sum \mathrm{P}_{\mathrm{b}}=$ the sum of proportions below the interval in which the median falls falls.

$\mathrm{P}_{\mathrm{w}}=$ the proportion within the interval in which the median $\mathrm{i}=$ the width of the interval and is assumed to be equal to 1.0

The scale values of statements shown in Table no.2

\section{Interquartile range or $Q$ Value}

It is the measure of the distribution of judgements for a given statements. The Interquartile range contains the middle 50 percent of the judgements. To determine the $\mathrm{Q}$ value, other two point measures i.e. $75^{\text {th }}\left(\mathbf{C}_{75}\right)$ and $25^{\text {th }}\left(\mathbf{C}_{25}\right)$ centile were needed which can be obtained from following formula.

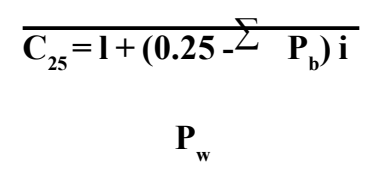

Where,

$\mathrm{C}_{25}=$ the $25^{\text {th }}$ percentile

$1=$ the lower limit of interval in which $25^{\text {th }}$ percentile falls

$\sum \mathrm{P}_{\mathrm{b}}=$ the sum of proportions below the interval in which $25^{\text {th }}$ percentile falls

$\mathrm{P}_{\mathrm{w}}=$ the proportion within the interval in which $25^{\text {th }}$ percentile falls

$\mathrm{i}=$ the width of the interval and is assumed to be equal to 1.0.

Similarly the $75^{\text {th }}$ percentile is given by,

$\mathbf{C}_{75}=\mathbf{l}+\left(\mathbf{0 . 7 5}-\mathbf{P}_{\mathrm{b}}\right) \mathbf{i}$

\section{$\mathbf{P}_{w}$}

Where,

$\mathrm{C}_{75}=$ the $75^{\text {th }}$ percentile

$1=$ the lower limit of interval in which $75^{\text {th }}$ percentile falls

$\sum \mathrm{P}_{\mathrm{b}}=$ the sum of proportions below the interval in which $75^{\text {th }}$ percentile falls

$\mathrm{P}_{\mathrm{w}}=$ the proportion within the interval in which $75^{\text {th }}$ percentile falls

$\mathrm{i}=$ the width of the interval and is assumed to be equal to 1.0 .

The Interquartile range or $\mathrm{Q}$ value was obtained by following formula. Large Q value is primary indication that statement is ambiguous.

$$
\mathbf{Q}=\mathbf{C}_{75}-\mathbf{C}_{25}
$$

\section{Sorting of statements}

The statements with the scale value above 1.60 and their $Q$ values below 1.60 were selected. Out of each 49 statements, 20 and 14 
statements having positive and negative perception were selected for dairy and goat production system respectively.

\section{Final format of scale and scoring of statements}

The three point continuum were agree, undecided and disagree with weights of 3, 2 and 1 respectively for favourable statements and 1, 2 and 3 for unfavourable statements respectively. The statements were given to ultimate 60 multistakeholders who were selected from animal husbandry department and KVKs for perception analysis. The responses were collected within the span of two months through mail and personal interview. The total individual respondent score was calculated by summing up the score of each statement given by individual.
The final format of selected statements given in Table 1.

\section{Reliability of the scales}

The reliability of the perception scales constructed was tested by split half and test-retest method.

\section{Split- half method}

All the 20 and 14 items of perception Scale were first arranged randomly and then divided into two halves. These two sets having 10 and 7 items each were administered to 30 respondents separately in non sample area. The co-efficient of correlation between two sets of scores was computed and the ' $r$ ' value of

Table 1 Final selected statements for scoring

S. No. Statements for Dairy production system

$1 \quad$ Dairy animals being used as dowry, gifts in religious rituals and rites $(+)$

2 Traditional dairy production system is effective in generating higher income $(+)$

3 Dairy farming helps to achieve high production through integration with different livestock enterprises $(+)$

$4 \quad$ Owning of good number of dairy animals brings prestige and social status $(+)$

5 Dairy production system helps to reduce poverty among smallholders $(+)$

$6 \quad$ Government support policy could not be helpful to increase profitability in dairy production system (-)

7 Low production potential of native breed does not affect the income level in dairy production(-)

$8 \quad$ Farmer prefers buffalo over cattle in dairy due to high price of buffalo milk $(+)$

9 Adoption of improved livestock technology could not increase the productivity of dairy animals (-)

10 Dairy farming is one of the most potential economic activity for most of smallholders $(+)$

11 Net annual return per milch animal is low in dairy production system (-)

12 Dairy production provides good source of income to rural women $(+)$

13 Information Network on Animal Heath Productivity (INAPH) application offers an opportunity for improving productivity of dairy animals $(+)$

14 Increasing urbanisation leads to demand for milk and milk products $(+)$

15 Purchasing price of cross breed cattle is not so high (-)

16 Single brand of milk in marketing does not assure fixed prices to milk and milk products (-)

17 Dairy production provide less employment compare to other livestock farming (-)

18 Productivity of cross breed cow is lower than buffalo (-)

19 Indigenous breeds are less productive than cross breed (-)

20 Dairy entrepreneurship promotes gainful employment among rural youth $(+)$

S.No. Statements for Goat production system

$1 \quad$ Goat has potential to contribute nutritional security $(+)$

$2 \quad$ Goat is being reared mostly as a primary source of income $(+)$

3 Goat farming generates good employment opportunity among the weaker sections of $\operatorname{society}(+)$

4 Goat production is not profitable income generating business for smallholders (-)

$5 \quad$ Goat farming gets more recognition in the society $(+)$

6 Government support policy could be helpful for increasing profitability $(+)$

$7 \quad$ Sale of goat and kid does not fetch remunerative prices to farmers (-)

8 Low production potential of native breed affect the income level of farmers(-)

9 Goat does not provides insurance against natural calamity (-)

10 Goat rearing is a risky enterprise for anyone as it easily get contract many diseases(-)

11 Broiler goat rearing is better option for meat goat farming in rural areas $(+)$

12 Goat can serve as mobile ATM for landless rural people $(+)$

13 Goat rearing is a good enterprise for anyone who wants to make some additional income for the family $(+)$

14 Goat cannot adapt to various agro-climatic conditions (-) 
0.82 and 0.76 was found to be significant at 1 percent level of The reliability co-efficient, thus obtained, indicated that the significance for dairy and goat production system respectively. "Internal consistency" of the perception Scale developed for the

Table 2 Final selected statements with scale and Q value

\begin{tabular}{|c|c|c|c|}
\hline$\overline{\text { S. No. }}$ & Statements & Scale value & Q value \\
\hline 1 & Dairy animals being used as dowry, gifts in religious rituals and rites & 3.83 & 1.00 \\
\hline 2 & $\begin{array}{l}\text { Traditional dairy production system is effective in generating higher } \\
\text { income }\end{array}$ & 3.00 & 1.34 \\
\hline 3 & $\begin{array}{l}\text { Dairy farming helps to achieve high production through integration with } \\
\text { different livestock enterprises }\end{array}$ & 2.57 & 1.10 \\
\hline 4 & Owning of good number of dairy animals brings prestige and social status & 2.04 & 0.91 \\
\hline 5 & Dairy production system helps to reduce poverty among smallholders & 2.33 & 0.78 \\
\hline 6 & $\begin{array}{l}\text { Government support policy could not be helpful to increase profitability in } \\
\text { dairy production system }\end{array}$ & 3 & 0.10 \\
\hline 7 & $\begin{array}{l}\text { Low production potential of native breed does not affect the income level } \\
\text { in dairy production }\end{array}$ & 2.83 & 0.50 \\
\hline 8 & Farmer prefers buffalo over cattle in dairy due to high price of buffalo milk & 1.78 & 0.43 \\
\hline 9 & $\begin{array}{l}\text { Adoption of improved livestock technology could not increase the } \\
\text { productivity of dairy animals }\end{array}$ & 2.33 & 0.75 \\
\hline 10 & $\begin{array}{l}\text { Dairy farming is one of the most potential economic activity for most of the } \\
\text { smallholders }\end{array}$ & 2.75 & 0.25 \\
\hline 11 & Net annual return per milch animal is low in dairy production system & 1.36 & 0.25 \\
\hline 12 & Dairy production provides good source of income to rural women & 3 & 0.34 \\
\hline 13 & $\begin{array}{l}\text { Information Network on Animal Heath Productivity (INAPH) application } \\
\text { offers an opportunity for improving productivity of dairy animals }\end{array}$ & 2.33 & 0.49 \\
\hline 14 & Increasing urbanisation leads to demand for milk and milk products & 1.9 & 0.5 \\
\hline 15 & Purchasing price of cross breed cattle is not so high & 2.3 & 1.5 \\
\hline 16 & $\begin{array}{l}\text { Single brand of milk in marketing does not assure fixed prices to milk and } \\
\text { milk products }\end{array}$ & 2.9 & 0.1 \\
\hline 17 & \multicolumn{2}{|l|}{ Dairy production provide less employment compare to other livestock farming 2} & 1 \\
\hline 18 & Productivity of cross breed cow is lower than buffalo & 2.9 & 1.04 \\
\hline 19 & Indigenous breeds are less productive than cross breed & 2.4 & 1.1 \\
\hline 20 & Dairy entrepreneurship promotes gainful employment among rural youth & 3.3 & 1.53 \\
\hline Sr.No & Statements for Goat production system & Scale value & Q value \\
\hline 1 & Goat has potential to contribute nutritional security & 1.9 & 0.5 \\
\hline 2 & Goat is being reared mostly as a primary source of income & 2.16 & 0.85 \\
\hline 3 & $\begin{array}{l}\text { Goat farming generates good employment opportunity among the weaker } \\
\text { sections of society }\end{array}$ & 2.16 & 0.90 \\
\hline 4 & $\begin{array}{l}\text { Goat production is not profitable income generating business for } \\
\text { smallholders }\end{array}$ & 1.94 & 0.40 \\
\hline 5 & Goat farming gets more recognition in the society & 2.75 & 1.00 \\
\hline 6 & $\begin{array}{l}\text { Government support policy could be helpful for increasing profitability in } \\
\text { goat production system }\end{array}$ & 2.10 & 0.65 \\
\hline 7 & Sale of goat and kid does not fetch remunerative prices to farmers & 2.16 & 0.70 \\
\hline 8 & Low production potential of native breed affect the income level of farmers & 2.30 & 1.30 \\
\hline 9 & Goat does not provides insurance against natural calamity & 2.07 & 1.20 \\
\hline 10 & $\begin{array}{l}\text { Goat rearing is a risky enterprise for anyone as it easily get contract many } \\
\text { diseases }\end{array}$ & 2.83 & 0.46 \\
\hline 11 & Broiler goat rearing is better option for meat goat farming in rural areas & 1.76 & 0.90 \\
\hline 12 & Goat can serve as mobile ATM for landless rural people & 2.13 & 1.23 \\
\hline 13 & $\begin{array}{l}\text { Goat rearing is a good enterprise for anyone who wants to make some } \\
\text { additional income for the family }\end{array}$ & 3.17 & 0.60 \\
\hline 14 & Goat cannot adapt to various agro-climatic conditions & 2.97 & 0.55 \\
\hline
\end{tabular}


study was quite high.

The stepped up reliability coefficient of the entire scale was calculated using Spearman brown formula.

Stepped up reliability $=2$ (Correlation found between two halves) $1+($ Correlation found between two halves $)$

Reliability of whole scale computed from above formula. The reliability for whole scale was found to be 0.90 and 0.86 for dairy and goat production system respectively which were found significant at 1 percent level of significance.

\section{Test-retest method}

The perception Scale with 20 and 14 items each was administered to 30 , respondents twice at interval of 15 days. The co-efficient of correlation value was 0.82 and 0.78 for dairy and goat production respectively which were found to be significant at 1 per cent level. Hence, the perception Scale constructed was highly stable and dependable for measurement.

\section{Content validity of perception Scale}

In the final selection of items, care was taken to include items covering the entire universe of relevant behavioural aspects of the respondents. Items were collected through various sources including specialists and hence it was assumed that the scores obtained by administrating this Scale measured the perception of the respondents as intended.

\section{Results and Discussion}

The finals scale consisting of 20 items ( 11 positive and 9 negative) for dairy and 14 ( 8 positive and 6 negative) items for goat production system were administered on 3 point continuum viz. Agree, Undecided and Disagree with weighatage of 3,2 and 1 for positive statements indicating favourableness and 1,2 and 3 for negative statements indicating unfavourableness. The overall possible score ranges between 0 to 42 for dairy and 0 to 30 for goat production system. Inclusion of positive and negative statements avoids prejudice judgement and will capture the actual perception reflected by the stakeholders. The final statements give scenario about livestock production system in the study area and its potential in terms of productivity, employment generation and income augmentation as perceived by stakeholders.

\section{Conclusions}

The perception of Multistakeholders reflected towards livestock production system is important in connection with doubling the farmers' income. To achieve the goal of doubling the farmers' income by 2022 , livestock production system is one of the viable option to augment farmers' income as perceived by stakeholders. Hence, a scale to measure perception of multistakeholders towards potential of dairy and goat production system has been developed. The perception scale can be used by future researchers also with suitable modifications to analyze the perception of stakeholders to assess potential of other livestock production systems in different agro-climatic zones.

\section{Acknowledgements}

I am thankful to all the official persons and faculty related with ICAR institutes, State veterinary universities and veterinary professionals for providing valuable judgement and suggestions for this study.

\section{References}

Anonymous (2017-18) Annual Report on Animal Husbandry, Dairying and fisheries retrieved from http://www.dahd.nic.in/reports/annualreport-2017-18 . Government of India, New Delhi.

$19^{\text {th }}$ Livestock Census (2012) Department of Animal Husbandry and Dairying,http://dahd.nic.in/sites/default/filess/ Livestock\%20\%205 0.pdf. Government of India, New Delhi

DFI Report (2017) Report of committee on Doubling Farmers' income, http://agricoop.nic.in/doubling-farmers .Vol XII

Edwards A L (1969) Techniques of attitude scale construction. Vakils, Feffer and simons, Inc, New York

National Dairy Development Board (NDDB) (2017) Milk production by states, http://www.nddb.coop/English/Statistics/Pages/ MilkProduction-States.aspx.

Singh MK, Dixit AK, Roy AK, Singh SK (2013) Goat rearing: A pathway for sustainable livelihood security in bundelkhand region: Agrilc Eco Res Rev 26:79-88

Van den Ban AW and Hawkins HS (1996) Agriculture extension. $2^{\text {nd }}$ edition, Blackwell science, Oxford 